\title{
EFFECT OF MOBILE BANKING SERVICES ON FINANCIAL PERFORMANCE OF DEPOSIT-TAKING SACCOS IN KENYA
}

\author{
${ }^{1}$ Everline Anyango Odipo, ${ }^{2}$ Dr. Onesmus Mutunga \\ ${ }^{1}$ School of Business, University Of Nairobi. \\ ${ }^{2}$ Lecturer, School of Business, University Of Nairobi.
}

DOI: 10.46609/IJSSER.2020.v05i05.009 URL:https://doi.org/10.46609/IJSSER.2020.v05i05.009

\begin{abstract}
The Sacco industry in Kenya has experienced growth in recent times through a tremendous rise of the quantity of licensed Deposit-Taking SACCOs (DTS) in Kenya as from when laws authorizing their establishment came into being in 1931. Over the years, these SACCOs have faced stiff competition for its customers from banks and other similar institutions offering financial services. Hence with the increased information technology innovations such as mobile phones, these SACCOs have had to adopt mobile banking as a mechanism of not only enhancing their operational efficiency but eventually improving their performance in terms of finances. The study required to find out effect of mobile banking services on the financial output of DTS in Kenya. It used descriptive research design such as mean, standard deviation and inferential statistics. Population of the study was the 166 DTS registered with SASRA by $31^{\text {st }}$ December 2018 and a sample of 117SACCOs were chosen through simple random sampling for inclusion into final sample. Secondary data comprising of the audited financial statements and reports for the sampled SACCOs ranging from the year 2015 to the year ending December 2018 obtained from SASRA were used in the study. Descriptive and inferential analysis methods were used. Multiple regression analysis was done to identify how phone banking adoption financially impacts the performance of Kenya's licensed DTS. It was established that MBS, asset protection, asset quality, capital adequacy, liquidity, costs and Sacco size positively influence financial performance in DTS and explained 69.4 percent of variations in financial performance while 30.6 percent is due to other factors not in the model. Capital Adequacy and Liquidity were found to know the financial performance of DTS to a greater extent. It was found that DTS growth in assets, deposits and loans is gradual. It concluded that mobile banking has enhanced the level that DTS reach members especially in the provision of deposit and withdrawal services as well
\end{abstract}


as limited digital credit by a few deposit taking SACCOs and recommends that the SACCOs that are yet to adopt the innovation should do so.

Keywords: SACCO, Mobile banking, Financial performance, Kenya
ABBREVIATIONS:
DIT
Disruptive Innovations Theory
DOI
Diffusion of Innovation Theory
DTS
Deposit Taking SACCOs
EPS
Earnings Per Share
EVA
Economic Value Added
IMF
International Monetary Fund

KUSCCO

Kenya Union of Savings and Credit Cooperative Ltd

MBS

Mobile Banking Services

NDTS

Non-Deposit Taking SACCOs

NIM

Net Interest Margin

PEARLS

Protection, Effective financial structure, Asset quality, Rates of return and costs, Liquidity and Signs of growth

ROA

Return on Assets

ROE

Return on Equity

ROI

Return on Investment

SACCO

Savings and Credit Co-operative

SASRA

Sacco Societies Regulatory Authority

TAM

Technology Acceptance Model

WOCCU

World Council of Credit Unions 


\section{CHAPTER ONE}

\section{INTRODUCTION}

\subsection{Background of the Study}

Most financial organizations have had to come with competitive strategies involving their products, innovations used, costs and differentiation to enhance their financial position (Aduda \& King'oo, 2012). One of the innovation strategies adopted by these institutions is to provide banking services through mobile banking. It basically refers to the use of innovations to perform financial transactions (Kingoo, 2011). Mobile banking is increasingly relevant due to competition on the international front, fragmented markets and diverse technologies. It has been linked to financial performance of these financial institutions as indicated by profit growth, revenue and the return on capital employed. Financial performance evaluates a firm's financial position as derived from its operations (Whittington \& Kurt, 2001).

Three main theories form the study's basis: Diffusion of Innovation Theory (DOI), Technology Acceptance Model (TAM) and Disruptive Innovations Theory (DIT). Diffusion of Innovation Theory explains how an innovation is adopted at different rates in a social system depending on the competitive advantage it has, the ease of use, ability to meet the user's needs among other variables. The Technology Acceptance Model - TAM argues that there has to be something unique about the people's perceptions, behavior and psychological predispositions that make them accept some technologies more readily than others (Tchouassi, 2012). The Disruptive Innovations Theory explains how the levels of acceptance of new innovations disrupt the market, affect and lead to differential monetary performance in DTS (Christensen, 2006).

The Savings and Credit Cooperative Societies (SACCOs) were formed as an innovative approach to address financial exclusion that negatively affected social and economic empowerment (Rogers, 1962; Wambari, 2009). SACCOs, which form part of the informal financial sector, aim to offer cheaper financial services (such as credit), flexible saving plans, and flexible repayment terms to the members that were previously ignored by the conventional financial institutions like banks (Kigen, 2010). Over years, SACCOs have had to diversify their activities and adopt competitive strategies to survive the dynamic market (Anyasi \& Otubu, 2009).

\subsubsection{Mobile Banking Services}




\section{International Journal of Social Science and Economic Research}

ISSN: $2455-8834$

Volume: 05, Issue: 05 "May 2020"

Ensor, Wannemacher and Montez (2012) defined phone banking to be the use of mobile devices for providing customers with communication, information in finance and dealings including transferring funds, account balance checking, and access of additional bank services and products anytime from any location. It utilizes the Wireless Application Protocol (WAP) and a user installed SIM card application for M-banking for facilitation of deposit for funds, withdrawals including transfer of value among parties such as bill payments, salaries and purchases (Hernandez, 2011). Financial institutions have had to partner with telecommunication companies to provide branchless banking methods such as mobile banking.

Over the years, banking activities have undergone radical changes precipitated by advances in information technology. The increased innovations in the digital cellular networks have led to powerful and widely distributed cellular networks that enable users to sufficiently transmit videos and huge documents and reduced cost of mobile phones (Laudon \& Laudon, 2007). This has largely contributed towards financial inclusiveness, provided a better substitute to other conventional digital bank channels like Automated Teller Machines and built branches, lowered the cost of delivering bank services through reduced paperwork and increased the convenience to customers by connecting the institutions to their customers through telecommunication networks (Ivatury \& Mas, 2008; O’Brien, 1993; Mwania, 2017).

Mobile banking services was assessed using the amount of mobile banking transactions in the period of study.

\subsubsection{Financial Performance}

This is how efficiently an entity utilizes its assets and manages its work over a specific duration of time (Ross, Westerfield \& Jordan, 2010). It is an evaluation of the financial health of an organization as a result of its operations, that is, it seeks to establish if the financial objectives of an organization have been achieved (Al-Hussein \& Johnson, 2009).

Efficient financial performance aims to maximize shareholders' wealth, thus rewarding them for investing and encouraging more investments that promote a country's economic growth (Nuhiu, Hoti \& Bektashi, 2017). Kivuvo, and Olweny (2014) note that, performance of a firm comprises of 4 elements within a multi-dimensional unit. Performance that is focused on the customer, comprising of market and financial performance; including profits, revenue, position in the market, share earnings, cash-to-cash cycle time; satisfaction of customers and service or product performance; performance of human resources, comprising satisfaction of employees; and effectiveness of the organization, including innovation level, time taken to market, and flexibility in the supply chain and production. 
International Journal of Social Science and Economic Research

ISSN: 2455-8834

Volume: 05, Issue: 05 "May 2020"

Generally, financial ratios for instance Earnings Per Share (EPS), Dividend Yield, Returnon Investment (ROI), profitability, Return on Assets (ROA) among others are for measuring the effectiveness and efficiency of an organization's operations (Jatmiko \& Hidayat, 2016). These indicators guide the management in picking thepolicies and strategies for adoption in improvement of the organization's sustainability (Almazari, 2011).

\subsubsection{Mobile Banking Services and Financial Performance}

As a form of electronic banking, mobile banking is a key part in reducing operation cost by saving on investment in physical infrastructure, improving products and services, and the general financial performance of banks (Beck, Dermigurc-Kunt \& Martinez, 2007; Dabholkhar \& Bagozzi, 2002). The availability of many outlets countrywide and flexible hours of work by mobile banking agents offer wider opportunities to meet the banking needs of clients throughout the day (Kariuki, 2009). According to the Global System for Mobile Communications (GSMA), over years figures of subscribers for mobile banking has been rising.

The studies aimed at the link between services in phone banking and financial performance of microfinance institutions are at their infancy (Al-Jabir, 2012). One of the reasons is that not many countries have adopted SIM-based MBS in the world (Kariuki, 2009; Njeri, 2013). As at 2011, there were just about 95 mobile banking ventures globally with M-PESA being one of the successfully launched mobile money services in Kenya (Klein \& Mayer, 2011)

Some analysts have linked the relative success of banking services using mobile phones in Kenya and other countries to people's mental or psychological faculties (Davis, 1989; Aboelmaged \& Gebba, 2013). Other analysts have related it to the fact that there were immense gaps in financial inclusion in those countries at the time when mobile banking services were introduced (Muteke, 2015; Kingoo, 2011; Kigen, 2010).

\subsubsection{Deposit-Taking SACCOs in Kenya}

Kenya's Savings and Credit Cooperatives (SACCOs) undergo registration as per the Cooperative Societies Act, 1997 and are supervised as per the Sacco Societies Act, 2008. They are defined by the Co-operative Societies Act, 1997Act as primary cooperatives comprising of voluntary associations formed to purposely promote the welfare and economic interests of their members.

SACCOs are divided into two types namely Non-Deposit Taking SACCOs (NDTS) and Deposit Taking SACCOs (DTS). Deposit-taking SACCOs receive demand deposits and therefore offer withdrawable savings accounts services like banks while the Non- Deposit Taking SACCOS take deposits which are only refundable to the member upon ceasing to be a member of a SACCO. 


\section{International Journal of Social Science and Economic Research}

ISSN: $2455-8834$

Volume: 05, Issue: 05 "May 2020"

SASRA, constituted under the Sacco Societies Act, 2008, is responsible for the regulation, licensing and supervision of deposit-taking SACCOs. By December 2018, Kenya had 166 licensed DTS.

Over the years, SACCOs have gradually automated their services moving from the traditional savings and loaning issues to an additional competitive and effective approach such as mobile banking that has positively affected their financial performance (Kiugi, 2018; Wanjiru, 2012; Oyugi, 2014).

\subsection{Research Problem}

MBS have greatly impacted the macro-economies of countries where the technologies have been extensively adopted (Lee, Lee \& Kim, 2007; Alkhatib, 2012; Tsuma et al, 2015). It has led to better quality products and services, increased customer base, reduced administrative and transaction cost and an increased financial performance of the banking institutions (Dabholkhar \& Bagozzi, 2002; Ombado, 2009; Mwania, 2017).

SACCOs were majorly formed to solve financial exclusion of the majority rural and urban populace who had been ignored by the mainstream financial institutions (Wambari, 2009). They have greatly improved the advancement of their members by providing tailor-made products and services. Most SACCO membership comprises people that were financially excluded by commercial banks Over time, SACCOs have had to adopt competitive strategies to face the dynamics of the market and counter the challenges faced. Mobile banking is one competitive strategy used by most SACCOs to outdo competitors in the market and make profits while enhancing their customers' convenience.

Different studies have been conducted regarding impact of innovations such as mobile services on various indicators in SACCOs' performance (Kiugu, 2018; Muteke, 2015; Tsuma et al. 2015; Wanjiru 2015). The studies established that such innovations positively affected the SACCOs' financial performance, cut down the operation costs, increased efficiency, and improved delivery of service. However, these studies focused on SACCOs in specific geographical locations and smaller sample size. Hence, these conclusions cannot be stated to be representative of all the SACCOs in the country. This reveals a gap in research particularly the association of banking innovation using mobiles in SACCOs and financial performance. Therefore, this study pursued to give an answer to the research question: What is the effect of mobile banking services in Kenya on monetary output of SACCOs?

\subsection{Research Objective}


The study sought to formulate the effect of MBS on financial performance of Kenya's Deposit Taking SACCOs.

\subsection{Value of the Study}

This study had hoped to assist the licensed SACCOs that are yet to adopt such an innovation or are doing so at a low rate, to see the importance of such a technology in improving their operations. It may also guide SACCOs' strategic planning and inform their decisions for investment in better programs for training and infrastructure that boost their MBS.

In addition, the government through regulatory bodies like SASRA may develop improved policies aimed at improving financial performance of SACCOs, curbing fraud related to mobile banking and providing incentives that reduce the cost of investing in such an innovation thus encouraging its wide use by even the small SACCOs.

Researchers and scholars could also benefit from the study to increase the pool of knowledge on adoption of banking using mobiles and its impact on SACCOs' performance in terms of financials.

\section{CHAPTER TWO}

\section{LITERATURE REVIEW}

\subsection{Introduction}

The chapter summarizes literary work that exists on the connection between MBS and financial outcome in diverse financial related institutions. It is divided into theoretical review, causes of financial performance, summary of the literature and empirical review.

\subsection{Theoretical Review}

The section reviews some theories which have been postulated to illustrate adoption of technology related innovations including banking using mobiles by most of the financial institutions across the world.

\subsubsection{The Diffusion of Innovations Theory}

Being a Rogers (1962) suggestion, the theory describes what happens as a new idea, object or philosophy is adopted by society (Kaminsky, 2011). Innovations refer to ideas, practice or an object being perceived to be new according to a particular social system's members while diffusion alludes to a process whereby an innovation gets transferred by particular channels/avenues for a time interval throughout a social system's membership. (Mahajan \& 


\section{International Journal of Social Science and Economic Research}

ISSN: $2455-8834$

Volume: 05, Issue: 05 "May 2020"

Peterson, 1985; Rogers, 1962). This theory comprises of three elements namely the innovation decision process, the adopter's characteristics and characteristics of an innovation characteristics.

The innovation decision process entails identifying the characteristics that influence adoption and categorizing adopting individuals (Christensen, 2006). The innovation attributes influencing adoption are its perceived relative advantage over other innovations, its compatibility with a person's needs, values, and past experience, an individual's comprehension of the complexity to learn and adopt the innovation, the level the individual can experiment with and use the new technology before full adoption and how much the new technology can be seen by others to be in use (observability), (Danneels, 2004; Tiwari, Buse \& Herstatt, 2006).

The diffusion process has 5 stages namely persuasion, knowledge, decision, confirmation, and implementation. Those interested in the innovation seek information on it and once convinced of its advantages, make a decision for adoption, implement it, and either reaffirm reject it (Rogers, 1983; Rogers, 1962). According to Rodgers, 1983 the adopters are grouped into early majority, innovators, late majority, laggards and early adopters as per when they accept an innovation. Innovators, comprising 2.5 per cent of the group are risk-takers with ample financial resources willing to sample fresh ideas, while the early adopters are mostly influential personalities in social settings and are 13.5 per cent of the group. The early majority deliberate before adoption while late majority are skeptical. Both comprise 34 per cent of the group while the laggards are the last 16 per cent of the adopters.

The theory explains how SACCOs decide to acquire technology for MBS after consideration that the qualities and capabilities of the innovation march the members' and institution's current needs which include improvement of SACCOs' financial performance.

\subsubsection{Technology Acceptance Model}

Davis (1989) proposed a model which forecasted adoption for new technologies in the information arena, specifically on acceptability for an information system, within an organization. The theory focuses on psychological predispositions and social influences such as intentions, beliefs, and attitudes. It was aimed at predicting how admissible a tool would be and to discern the necessary modifications to this system so that it is acceptable for users. This theory proposed that an information system's potential usefulness or perceived ability to be used were factors determining its acceptability.

Davis further noted that an individual considered the effect a system has on performance for an individual's apart from just their outlook towards the system. Attitude on usage of that particular system and the expected usefulness determines the behavioral intention. Consequently, attitude is determined by both the opinion on ease of utilization and the apparent benefit from the system 


\section{International Journal of Social Science and Economic Research}

ISSN: $2455-8834$

Volume: 05, Issue: 05 "May 2020"

(Davis, 1989). It is definitely a convincing explanation of the increased performance of SACCOs reported in literature. For instance, it appears that it is because of widespread acceptance, coupled with exclusions from the mainstream financial sector, that more people opted to send their savings using mobile money instead of having to physically travel to the financial institution.

The theory indicates the various factors considered by SACCOs before investing in mobile enabled services in banking. These include the contemplated simplicity in use and functionality and the influence on its financial performance. The theory also cautions SACCOs to sensitize both employees and clients on the new technology's utilization adopted for improving service and importantly, financial performance.

\subsubsection{Disruptive Innovation Theory}

Proposed by Christensen in a series of studies conducted between 1997 and 2006 (Christensen, 2006), the theory explains how a service or product lodges itself first through basic ways at lowest levels of a market. The product then in a sustaining and relentless manner scales a market upwards to eventually replace the already present competitors.

It essentially proceeds from four key elements with the first proposing that those already in a market are developing by following a path that sustains innovation (King \& Baartartogtokh, 2015). However, innovating companies or technologies have a distinctly different trajectory to introduce new and improved products or through a sustaining innovation. Second is that incumbents overshoot customer needs, third is that incumbents have the ability to act upon threats which are disruptive, while fourth is when they finally fail after being disrupted.

This theory essentially explains how a service or product lodges itself first through basic ways at lowest levels of a market. The product then in a sustaining and relentless manner scales a market upwards to eventually replace the already present competitors. It would thus explain the low financial performance in SACCOs following the introduction of mobile banking and the subsequent rise in performance after a period of time.

\subsection{Determinants of Financial Performance}

SACCOs' performance just like for other institutions in the financial sector including banks are influenced by macroeconomic and organization-specific elements (Al-Tamimi, 2010).

The World Council of Credit Unions (WOCCU, 2009) recommends utilizing PEARLS system, comprising of several financial-ratios able to quantify individual factors as well as the whole 
system, hence an early warning system against unseen financial risk in SACCOs. This acronym is broken down as follows:

\subsubsection{Protection}

Protection is adequate when a SACCO can cover all bad loans delinquent over a period of one year and $35 \%$ of bad loans delinquent over a period of between one to twelve months (WOCCU, 2009).

The provision for loan-loss is a significant factor of the variations in capital positions and bank profitability as a lower loan- loss provision translates to higher profits (Mustafa, Ansari \& Younis 2012).

\subsubsection{Effective financial structure}

It helps determine a SACCO's earnings capacity, growth potential and general financial strength. It shows how financing of assets and capacity of the institution to take care of losses (Hassan \& Bashir, 2003).

WOCCU, 2009 recommends a credit union to have $95 \%$ productive assets comprising of $70-80 \%$ loans, liabilities of $70-80 \%$ member deposits, $10-20 \%$ share capital. Suggestions for investment include net loan $(70-80 \%)$, liquid assets (20\%), financial assets (10\%) and investments which are not financial (0\%) (WOCCU, 2009).

\subsubsection{Asset quality}

The measure seeks to establish the effect of the non-earning assets on profitability and solvency. WOCCU recommends the ration to be less than or equal to $5 \%$.

The lower the level of non-performing assets, the better the management of credit risk which translates to better asset quality (Swamy 2013). High delinquency indicates a weakness in other important credit union areas of operations such as the institutional capital, net income and provisions in losses from loans (Baral, 2006).

\subsubsection{Rates of return and costs}

Its indicators quantify average income yield from all the most productive assets of the Balance Sheet and average yield of each of the liability and capital accounts (WOCCU, 2009).

It entails monitoring the return earnings from every asset type i.e. determining the kinds of assets which would bring the most returns, and cost of every kind of liability determining the least expensive sources of funds. This ensures control of the operating costs (Baral, 2006). 


\subsubsection{Liquidity}

The indicators point out whether there is effective management of cash to enable the credit union fulfill deposit withdrawal claims and liquidity reserve obligations.

A large liquidity gap may cause banks to take on higher interest rate loans from the repo market thereby increasing the cost of the banks. The increased cost will eventually affect the bank's profitability (Maaka, 2006).

There is need to establish a balance between the need to maximize profit and preserving liquidity as enhancing profits at the expense of liquidity can cause major challenges to a banking institution (Sufian \& Chong, 2008).

\subsubsection{Signs of growth}

According to WOCCU (2009), the indicators in this variable seek to determine the proportion of gain in each of the very crucial accounts in the financial statements and the membership growth.

The growth of an institution in terms of loans, saving, total assets, among others reflects satisfaction for member and client, suitability of what the product offers and strength in the financial issues. However, growth and profitability are to some extent competing objectives and interdependent (Goddard, Molyneux \& Wilson, 2001)

\subsection{Empirical Review}

Recent literature on the topic of study has focused mainly on the taking up of banking using mobiles by deposit taking SACCOs for certain regions/ county in the country.

Aboelmaged and Gebba (2013) sought to considered components that influenced mobile banking adoption in the United Arab Emirates (UAE). Survey data, collected through self-administered questionnaire, from 119 respondents was analyzed where they found that attitude and expected usefulness substantially influenced adoption of banking using mobiles. Conversely, influence of control in behavior and its importance on adoption of banking by mobiles phones were unimportant.

Daud, Kassim, Said, and Noor (2011) in a study, looked at the variables affecting phone banking adoption for the Malaysia market by means of advanced Technology Acceptance Model (TAM). Survey data gathered from about 300 users of banking services on their opinions on mobile banking was empirically evaluated. They found that perceived helpfulness and perceived credibility or users' perception on the safety transactions details and private data from unauthorized access affected adoption of mobile banking. 


\section{International Journal of Social Science and Economic Research}

ISSN: $2455-8834$

Volume: 05, Issue: 05 "May 2020"

Sonja (2010) aimed at establishing how automation affected the growth of Ugandan SACCOs. Information ranging from 2005-2010 was collected on five of the eight SACCOs from the midnorth and southern region of Uganda. Her findings implied that automation of SACCOs services lead to efficiency in running the SACCOs, customer growth, increased transparency and generation of different accurate financial reports.

Crabbe et al (2009) sought to establish and examine factors influencing phone banking adoption behavior for Ghana. Data gathered by using a self-administered, closed questionnaire issued to 271 people from diverse segments was analyzed through stepwise regression analysis. It was established that adoption decisions were easily swayed by cultural and social factors including demographic factors, apparent credibility, facilitating conditions, and incorporating social impacts including building an image and peer influence. The latter can positively influence those who adopt while at the same time negatively influencing those who do not adopt. Additionally, facilitating conditions and expected credibility have an impact on attitudes to technology.

Kosmidou (2008) looked at the factors impacting on bank performance in Greece between 1990 and 2002 when there was the EU integration. Using a time series data set which was unbalanced pooled from 23 banks, they established that banks that were well-capitalized and that had lower ratio of cost to income got high returns on average assets (ROAA). This return was realized as positively affected by the growth in Gross domestic product (GDP) and negatively affected by inflation.

Mwania (2017) aimed at establishing the correlation between financial performance and growth for Kenyan SACCOs. More specifically, he sought to assess how return on assets affects growth of SACCOs, the effect of innovation in SACCO growth, the extent at which return on equity affect growth of SACCOs, and how earnings per share affect growth of SACCOs. Secondary and primary data ranging from 2012 to 2016 on 42 out of the target population of 175 deposit taking licensed SACCOs underwent analysis using a multivariate model of regression. Findings indicated Return on Equity increases the growth of SACCOs while Earnings per Share and Return on Assets decrease this increase. It concluded that financial performance positively impacted on development in SACCOs.

Wanjiru (2015) investigated how SACCO services impacted using mobiles had on performance in terms of finances of the 42 DTS located in Nairobi. The data obtained from audited statements of finance over a period of four years $(2011$ - 2014) underwent analysis through a model of regression that was linear. It was discovered that the quality in management, investment for MSacco services, and amount of transactions for M-Sacco positively conducted and significantly affected the financial performance in SACCOs. It further came to the conclusion that a negative and an important link exists between SACCO size and performance in finances of SACCOS. The 
findings cannot be wholly adopted as applying to all SACCOs that are licensed and take deposits.

Kiaritha (2015) established positive association between performance in finances of Kenya SACCOs operating in the banking industry and its effects such as internal politics, commercial banks' competition, costs for operations, investment policy and culture of savings. It was determined that the study variables were significant statistically in the explanation of financial performance of the banking sector's SACCOs and urged SACCOs to be implement effective strategic plans and investment policies and be proactive for it to obtain competitive advantage above its opponents.

Kivuvo and Olweny (2014) looked at how deposit-taking SACCOs in Kenya performed financially through Altiman's Z score model of corporate insolvency prediction. Longitudinal data from statements of finance in the duration ranging between 2008 and 2013 for 30 out of Kenya's 215 registered SACCOs taking deposits was analyzed. The studies established that the Altiman Z Score Model is a strong tool for financial analysis. In addition, they found out that the variables $X_{1}$ i.e. working capital to Total assets and $X_{4}$ i.e. equity to Total book debt significantly influence the way SACCOs performed. It further concluded that the model application contributes to financial stability. The model is a good tool for measuring SACCOs' financial performance as it factors profitability, liquidity and solvency potential of the SACCOs.

Oyugi (2014) investigated how automated service affected the financial performance in 130 licensed SACCOS. Secondary and primary data ranging from year 2009 to 2013 for 45 of the SACCOs from Kiambu and Nairobi Counties were analysed through a model of multiple regression. They concluded that automated services did affect positively the financial performance of SACCOS. The sample used was not objectively identified. Hence, the conclusions arrived at cannot be used to generalize about all the SACCOs in the population. 


\subsection{Conceptual Framework}

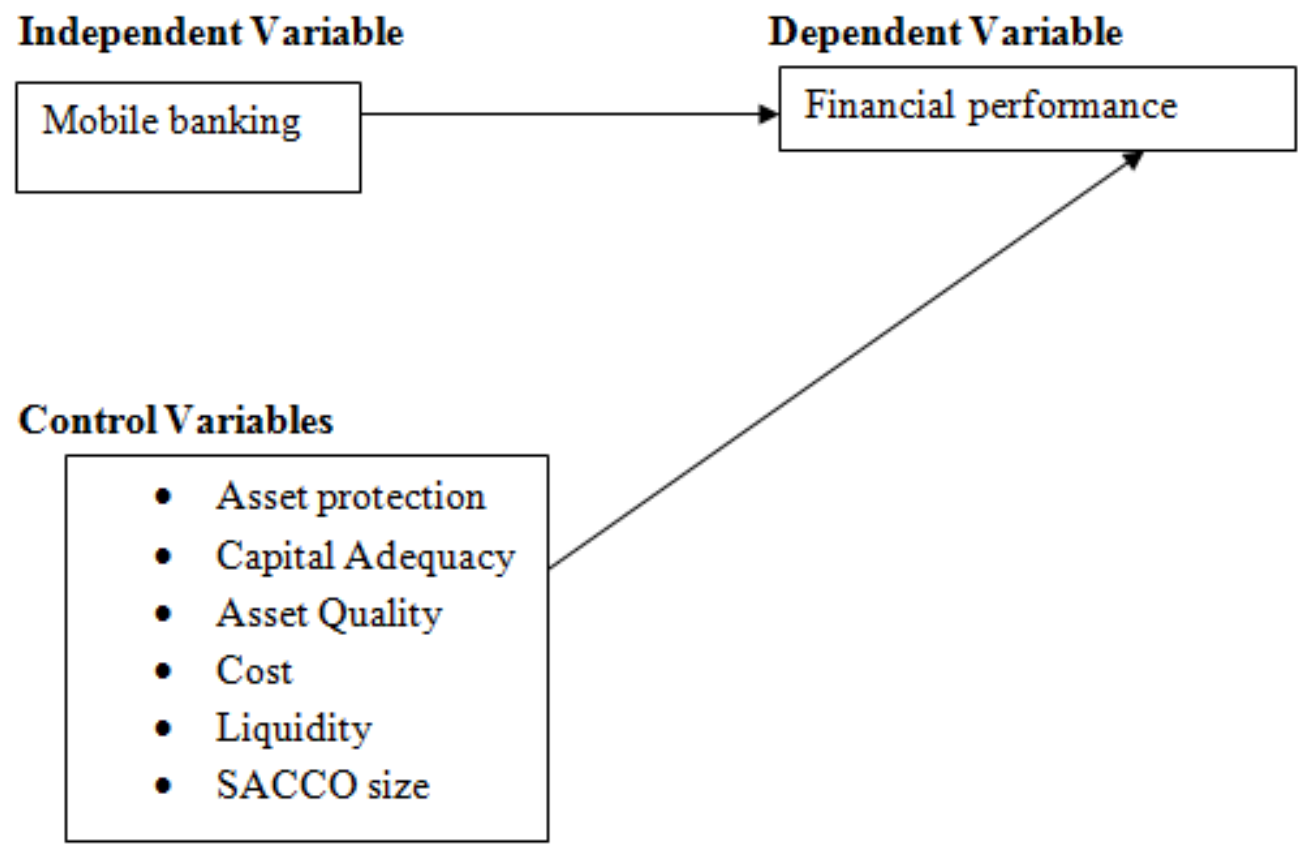

\section{Source: (WOCCU PEARLS monitoring framework)}

In this study, financial performance will be assessed through division of net income after tax with total assets; mobile banking services by logarithm of number of mobile banking transactions; asset protection by dividing the loan loss provision by total loans; the capital adequacy will be measured by getting total assets percentage sourced from capital; the asset quality by dividing total non-earning assets by total assets; cost by logarithm of expenses related to mobile banking and SACCO size will be measured by total deposits while financial performance will be measured by profitability.

\subsection{Summary of Literature Review and Research Gap}

While examining factors that influenced phone banking adoption, several researchers found attitude of users cultural and social factors significantly impacted mobile banking positively, led to efficiency in running the SACCOs, customer growth, increased transparency and generation of different accurate financial reports for SACCOs (Crabbe et al. 2009; Sonja, 2010; Daud et al. 2011; Aboelmaged \& Gebba, 2013; Oyugi 2014). 
Other researchers established performance of banks was influenced by Gross domestic product (GDP), inflation, management quality, investment in M-Sacco services, and quantity of M-Sacco bank activities (Kosmidou, 2008; Wanjiru, 2015) while others established that financial performance had a positive bearing on the growth in SACCOs (Mwania, 2017).SACCOs' financial performance could be measured by Altman's Z score model as it factors the profitability, liquidity and solvency potential of the SACCOs (Kivuvo \& Olweny, 2014).

Most empirical evidence collected, especially from international studies, mainly focused on banks in the commercial sector and factors influencing introduction of mobile banking in the banks while other studies focused on SACCOs located in specific geographical locations and smaller sample sizes. Thus the conclusions drawn from the studies cannot be used to generalize about Kenya's SACCOs.

\section{CHAPTER THREE}

\section{RESEARCH METHODOLOGY}

\subsection{Introduction}

The section covers the study's research design, defines study population and specified the approach used in the sampling process. Methods for data collection used are outlined and approach to analysis of data specified.

\subsection{Research Design}

Descriptive research design was used as it offers summary for the observed attribute of the dependent and independent variants (Kothari, 2005; Cooper \& Schindler, 2006).

\subsection{Population}

Population refers to a cluster of items or persons from which there is need to obtain information (Harper, 1991). The population target for the study included 166 Deposit-Taking SACCOs registered with SASRA as of $31^{\text {st }}$ December 2018.

\subsection{Sample Design}

Sample is a finite portion drawn from the population with characteristics examined for gaining information concerning a whole entity (Cooper \& Schindler, 2006). This study used simple random sampling to choose117 SACCOs identified through the formula provided by Yamane (1967) shown below:

$$
\mathrm{n}=\quad \mathrm{N}
$$




$$
1+\mathrm{N}(\mathrm{e})^{2}
$$

Where:

$\mathrm{n}=$ sample size

$\mathrm{N}($ population $)=166$

e $($ extent of precision $)=5 \%$ at $95 \%$ confidence level

Therefore:

$$
\begin{aligned}
\mathrm{n}= & \frac{166}{1+166(0.05)^{2}} \\
& =117 \mathrm{SACCOs}
\end{aligned}
$$

\subsection{Data Collection Technique}

Secondary data comprising of audited financial statements and reports for the sampled SACCOs ranging from the year 2015 to the year ending December 2018 obtained from SASRA were used in the study.

\subsection{Data Analysis}

In line with the research design, and as advised in Cooper and Schindler (2006), both inferential and descriptive analysis methods were used. Descriptive analysis was essential for running frequencies while inferential analysis were for testing hypotheses related to financial performance and mobile banking. Results were presented in tables.

\subsubsection{Analytical Model}

A multiple regression analysis was done with a view of establishing how the adoption of phone banking impacts on fiscal outcome of the licensed DTS in Kenya. It used the following regression simulation:

$$
\mathrm{Y}=\beta_{\mathrm{o}}+\beta_{1} \mathrm{X}_{1}+\beta_{2} \mathrm{X}_{2}+\beta_{3} \mathrm{X}_{3}+\mathrm{B}_{4} \mathrm{X}_{4}+\mathrm{B}_{5} \mathrm{X}_{5}+\mathrm{B}_{6} \mathrm{X}_{6}+\mathrm{B}_{7} \mathrm{X}_{7}+\varepsilon
$$

Where:

$\mathrm{Y}=$ financial performance of SACCOs assessed by profitability 
$\beta_{0}=$ constant term/coefficient of intercept;

$\beta_{\mathrm{n}>0}=$ Coefficients of $X_{n}$

$\mathrm{X}_{1}=$ the number of mobile banking transactions;

$\mathrm{X}_{2}=$ Asset protection

$\mathrm{X}_{3}=$ Capital adequacy

$\mathrm{X}_{4}=$ Asset quality

$\mathrm{X}_{5}=$ Cost

$\mathrm{X}_{6}=$ Liquidity

$\mathrm{X}_{7}=\mathrm{SACCO}$ size

$\varepsilon=$ error term

\subsubsection{Operationalization of Variables}

The parameters examined and how they are measured included the following:

Table 3.1: Operationalization and Measurement of Variables

\begin{tabular}{|c|c|c|c|c|c|}
\hline VARIABLE & $\begin{array}{l}\text { VARIABLE } \\
\text { TYPE }\end{array}$ & INDICATORS & OPERATIONALISATION & $\begin{array}{c}\text { LEVEL OF } \\
\text { MEASUREMENT }\end{array}$ & REFERENCE \\
\hline PERFORMANCE & Dependent & Profitability & $\begin{array}{c}\text { Net income after tax/total } \\
\text { assets }\end{array}$ & Ratio scale & Almazari, 2011 \\
\hline $\begin{array}{c}\text { MOBILE } \\
\text { BANKING } \\
\text { SERVICE }\end{array}$ & Independent & $\begin{array}{l}\text { mobile banking } \\
\text { transactions }\end{array}$ & $\begin{array}{l}\text { Logarithm of number of } \\
\text { mobile banking transactions }\end{array}$ & Ratio scale & $\begin{array}{l}\text { Crabbe, Standing } \\
\text { \&Karjaluoto, } 2009\end{array}$ \\
\hline $\begin{array}{c}\text { ASSET } \\
\text { PROTECTION }\end{array}$ & Control & $\begin{array}{c}\text { Provision for loan } \\
\text { loss }\end{array}$ & $\begin{array}{c}\text { Loan loss provision/total } \\
\text { loans }\end{array}$ & Ratio scale & $\begin{array}{l}\text { WOCCU, 2009; } \\
\text { Mustafa, Ansari \& } \\
\text { Younis, } 2012\end{array}$ \\
\hline $\begin{array}{c}\text { CAPITAL } \\
\text { ADEQUACY }\end{array}$ & Control & $\begin{array}{l}\text { total assets } \\
\text { financed by capital }\end{array}$ & $\begin{array}{l}\text { Percentage of total assets } \\
\text { financed by capital }\end{array}$ & Ratio scale & $\begin{array}{l}\text { WOCCU, 2009; } \\
\text { Hassan \& Bashir, } \\
\text { 2003). }\end{array}$ \\
\hline $\begin{array}{c}\text { ASSET } \\
\text { QUALITY }\end{array}$ & Control & $\begin{array}{l}\text { Total assets not } \\
\text { earning income }\end{array}$ & $\begin{array}{c}\text { Total non-earning assets/total } \\
\text { assets }\end{array}$ & Ratio scale & $\begin{array}{l}\text { WOCCU, 2009; Baral, } \\
\text { 2006; Swamy 2013). }\end{array}$ \\
\hline COSTS & Control & $\begin{array}{c}\text { Cost of managing } \\
\text { asset }\end{array}$ & $\begin{array}{c}\text { Expenses incurred from } \\
\text { mobile banking by SACCOs }\end{array}$ & Ratio scale & Baral, 2006 \\
\hline LIQUIDITY & Control & $\begin{array}{c}\text { Cash available for } \\
\text { withdrawal }\end{array}$ & $\begin{array}{c}\text { Liquidity reserve/savings } \\
\text { deposits }\end{array}$ & Ratio scale & $\begin{array}{l}\text { WOCCU, 2009; Sufian } \\
\quad \text { \& Chong, } 2009\end{array}$ \\
\hline
\end{tabular}


Volume: 05, Issue: 05 "May 2020"

\begin{tabular}{|c|c|c|c|c|c|}
\hline SACCO SIZE & Control & Total deposits & $\begin{array}{c}\text { Logarithm of total deposits } \\
\text { made in SACCOs }\end{array}$ & Ratio scale & $\begin{array}{c}\text { Goddard, Molyneux } \\
\boldsymbol{\&} \text { Wilson, 2001 }\end{array}$ \\
\hline
\end{tabular}

\subsubsection{Diagnostic Tests}

The Kolmogorov-Smirnov normality test was used to check for data normality.

\subsubsection{Tests of Significance}

This study examined the statistical significance level at 95\% significance confidence level. Relevance of the model was determined by employing the F-test at $5 \%$ level of significance to decide on rebuffing or accepting the null hypothesis that none of coefficients of independent variants can predict financial performance.

\section{CHAPTER FOUR}

\section{DATA ANALYSIS, FINDINGS AND DISCUSSIONS}

\subsection{Introduction}

The chapter gives study results and uses tables for reviewing data. Findings and the collected data analysis were processed in order to respond to the research objective. The aim of the study was to find out the effect of MBS on financial output of Kenya's DTS.

\subsection{Diagnostic Tests}

The diagnostic tests that were done include the Kolmogorov-Smirnov normality test. This was done to test normality with the null hypothesis that the independent variables' data did not originate from a population which is distributed non-normally. All results from the diagnostic tests show that all the variables were derived from a normally distributed population as indicated in the table below.

Table 4.1: Diagnostic Tests

\begin{tabular}{|l|c|c|c|}
\hline & \multicolumn{3}{|c|}{ Kolmogorov-Smirnov } \\
\hline & Statistic & df & Sig. \\
\hline Mobile Banking Services & 0.089 & 117 & 0.196 \\
\hline Asset Protection & 0.086 & 117 & 0.197 \\
\hline Capital Adequacy & 0.085 & 117 & 0.190 \\
\hline Asset Quality & & & 0.198 \\
\hline
\end{tabular}




\begin{tabular}{|l|l|l|l|}
\hline Costs & 0.084 & 117 & 0.194 \\
\hline Liquidity & 0.087 & 117 & 0.196 \\
\hline Sacco Size & 0.086 & 117 & 0.195 \\
\hline Performance & 0.084 & 117 & 0.194 \\
\hline
\end{tabular}

Source: Survey Data (2019)

\subsection{Descriptive Statistics}

Data was descriptively analyzed to summarize and reveal the characteristics of the data collected. MBS showed a 3.49 average mean and 0.33 standard deviation as shown below, which indicates that the service was not used by SACCOs and their members extensively. However, one popular area of mobile banking was mobile money transfer due to low charges and convenience than financial institutions. Majority of the deposit taking SACCOs also maintained a healthy capital adequacy ratio over the period with an average of $13.93 \%$. The results also indicate that SACCO growth has been rapid over the four- year period as evidenced by the increase in deposits.

Table 4.2: Descriptive data

\begin{tabular}{|l|c|c|c|c|c|c|}
\hline & $\mathbf{2 0 1 8}$ & $\mathbf{2 0 1 7}$ & $\mathbf{2 0 1 6}$ & $\mathbf{2 0 1 5}$ & Mean & Std Dev \\
\hline $\begin{array}{l}\text { Mobile } \\
\text { Banking } \\
\text { Services }\end{array}$ & 3.97 & 3.42 & 3.31 & 3.24 & $\mathbf{3 . 4 9}$ & $\mathbf{0 . 3 3}$ \\
\hline $\begin{array}{l}\text { Asset } \\
\text { Protection }\end{array}$ & $4.53 \%$ & $4.28 \%$ & $3.86 \%$ & $3.83 \%$ & $\mathbf{4 . 1 3 \%}$ & $\mathbf{0 . 3 4}$ \\
\hline $\begin{array}{l}\text { Capital } \\
\text { Adequacy }\end{array}$ & $15.08 \%$ & $14.53 \%$ & $13.96 \%$ & $12.17 \%$ & $\mathbf{1 3 . 9 3 \%}$ & $\mathbf{1 . 2 6}$ \\
\hline Asset Quality & $6.98 \%$ & $6.14 \%$ & $5.23 \%$ & $5.12 \%$ & $\mathbf{5 . 8 6 \%}$ & $\mathbf{0 . 8 7}$ \\
\hline Costs & $45.02 \%$ & $43.99 \%$ & $41.35 \%$ & $41.58 \%$ & $\mathbf{4 2 . 9 9 \%}$ & $\mathbf{1 . 8 1}$ \\
\hline Liquidity & $54.72 \%$ & $54.10 \%$ & $49.95 \%$ & $55.90 \%$ & $\mathbf{5 3 . 6 7 \%}$ & $\mathbf{2 . 5 9}$ \\
\hline $\begin{array}{l}\text { Sacco Size } \\
\text { (Millions) }\end{array}$ & 2,126 & 1,754 & 1,548 & 1,341 & $\mathbf{1 , 6 9 2}$ & $\mathbf{3 3 4 . 7 3}$ \\
\hline Performance & 0.026 & 0.025 & 0.020 & 0.022 & $\mathbf{0 . 0 2 3}$ & $\mathbf{0 . 0 2 8}$ \\
\hline Souce: Surve Ding & & & & & & \\
\hline
\end{tabular}

Source: Survey Data (2019) 
Tests for skewness and kurtosis were also done as indicated in the table below. The positive values indicate that the variables' data were positively skewed and leptokurtic but not perfectly normally distributed.

Table 4.3: Skewness and kurtosis

\begin{tabular}{|l|c|c|c|c|}
\hline & \multicolumn{2}{|c|}{ Skewness } & \multicolumn{2}{c|}{ Kurtosis } \\
\hline & Statistic & Std & Statistic & Std \\
& & Error & & Error \\
\hline Mobile Banking Services & 3.741 & 0.031 & 0.635 & 0.382 \\
\hline Asset Protection & 2.138 & 0.255 & 0.854 & 0.299 \\
\hline Capital Adequacy & 3.562 & 0.214 & 0.057 & 0.398 \\
\hline Asset Quality & & & & 0.274 \\
\hline Costs & 1.816 & 0.471 & 1.851 & 0.197 \\
\hline Liquidity & 2.639 & 0.195 & 2.328 & 0.256 \\
\hline Sacco Size & 0.088 & 0.196 & 3.723 & 0.253 \\
\hline Performance & 1.936 & 0.159 & 1.823 & 0.069 \\
\hline
\end{tabular}

Source: Survey Data (2019)

\subsection{Correlation Analysis}

When the independent variables were correlated among themselves, all were found to be associated as indicated in Table below.

Table 4.4: Correlation Matrix

\begin{tabular}{|c|c|c|c|c|c|c|c|c|}
\hline & Performance & $\begin{array}{c}\text { Mobile } \\
\text { Banking } \\
\text { Services }\end{array}$ & $\begin{array}{c}\text { Asset } \\
\text { Protection }\end{array}$ & $\begin{array}{c}\text { CapitalAd } \\
\text { equacy }\end{array}$ & $\begin{array}{c}\text { Asset } \\
\text { Quality }\end{array}$ & Costs & Liquidity & $\begin{array}{c}\text { Sacco } \\
\text { Size }\end{array}$ \\
\hline $\begin{array}{c}\text { Pearson } \\
\text { Porrelation } \\
\text { Sig. (2-tailed) }\end{array}$ & 1 & $.250^{*}$ & .421 & .513 & $.754^{* *}$ & .402 & .621 & .325 \\
& & .014 & .165 & .023 & .076 & .082 & .048 & .073
\end{tabular}


International Journal of Social Science and Economic Research

ISSN: $2455-8834$

Volume: 05, Issue: 05 "May 2020"

\begin{tabular}{|c|c|c|c|c|c|c|c|c|c|}
\hline & $\mathrm{N}$ & 117 & 117 & 117 & 117 & 117 & 117 & 117 & 117 \\
\hline \multirow{3}{*}{$\begin{array}{l}\text { Mobile } \\
\text { Banking } \\
\text { Services }\end{array}$} & $\begin{array}{l}\text { Pearson } \\
\text { Correlation }\end{array}$ & $.250^{*}$ & 1 & .221 & .299 & .225 & .223 & .220 & .210 \\
\hline & Sig. (2-tailed) & .014 & & .014 & .038 & .006 & .185 & .093 & .036 \\
\hline & $\mathrm{N}$ & 117 & 117 & 117 & 117 & 117 & 117 & 117 & 117 \\
\hline \multirow{3}{*}{$\begin{array}{c}\text { Asset } \\
\text { Protection }\end{array}$} & $\begin{array}{l}\text { Pearson } \\
\text { Correlation }\end{array}$ & .421 & .221 & 1 & .332 & .362 & .372 & .498 & .321 \\
\hline & Sig. (2-tailed) & .165 & .014 & & .139 & .068 & .191 & .030 & .152 \\
\hline & $\mathrm{N}$ & 117 & 117 & 117 & 117 & 117 & 117 & 117 & 117 \\
\hline \multirow{3}{*}{$\begin{array}{c}\text { CapitalAdeq } \\
\text { uacy }\end{array}$} & $\begin{array}{c}\text { Pearson } \\
\text { Correlation }\end{array}$ & .513 & .299 & .332 & 1 & $.338^{*}$ & .453 & .353 & .313 \\
\hline & Sig. (2-tailed) & .023 & .038 & .139 & & .182 & .236 & .035 & .223 \\
\hline & $\mathrm{N}$ & 117 & 117 & 117 & 117 & 117 & 117 & 117 & 117 \\
\hline \multirow{3}{*}{$\begin{array}{l}\text { Asset } \\
\text { Quality }\end{array}$} & $\begin{array}{c}\text { Pearson } \\
\text { Correlation }\end{array}$ & $.754^{* *}$ & .225 & .362 & $.338^{*}$ & 1 & .342 & .391 & .378 \\
\hline & Sig. (2-tailed) & .076 & .006 & .068 & .182 & & .053 & .147 & .047 \\
\hline & $\mathrm{N}$ & 117 & 117 & 117 & 117 & 117 & 117 & 117 & 117 \\
\hline \multirow{3}{*}{ Costs } & $\begin{array}{c}\text { Pearson } \\
\text { Correlation }\end{array}$ & .402 & .223 & .372 & .453 & .270 & 1 & .395 & .302 \\
\hline & Sig. (2-tailed) & .082 & .185 & .191 & .236 & .031 & & .077 & .028 \\
\hline & $\mathrm{N}$ & 117 & 117 & 117 & 117 & 117 & 117 & 117 & 117 \\
\hline \multirow{3}{*}{ Liquidity } & $\begin{array}{c}\text { Pearson } \\
\text { Correlation }\end{array}$ & .621 & .220 & .498 & .353 & .391 & .395 & 1 & .261 \\
\hline & Sig. (2-tailed) & .048 & .093 & .030 & .035 & .147 & .077 & & .084 \\
\hline & $\mathrm{N}$ & 117 & 117 & 117 & 117 & 117 & 117 & 117 & 117 \\
\hline \multirow{3}{*}{ Sacco Size } & $\begin{array}{l}\text { Pearson } \\
\text { Correlation }\end{array}$ & .325 & .210 & .321 & .313 & .378 & .302 & .261 & 1 \\
\hline & Sig. (2-tailed) & .073 & .036 & .152 & .223 & .047 & .028 & .084 & \\
\hline & $\mathrm{N}$ & 117 & 117 & 117 & 117 & 117 & 117 & 117 & 117 \\
\hline
\end{tabular}

*. Correlationis significant at the 0.05 level (2-tailed)

**. Correlation is significant at the 0.01 level (2-tailed).

There was a correlation which was positive among all the variables. Financial performance was significantly and positively correlated with mobile banking services, while although it is positively correlated to the other variables, the correlation is not statistically important.

All control variables are positively correlated to each other but the correlation between most of the control variables was not statistically significant as most had significant values greater than 0.01 , implying that the correlation was just by chance and not an indication it exists in the population. 


\subsection{Regression Analysis}

A multiple linear regression analysis of the data was done to determine the linear association between MBS and financial output of DTS over the period 2015 - 2018. Coefficient of determination offers an explanation of the extent to which adjustments in the independent parameters explain the shifts in the dependent parameters. Regression outcome on the coefficient of determination are summarized below.

\subsubsection{Summary of Regression Model Results}

Regression analysis to determine the influence of MBS on financial output was also done. The adjusted R-Squared is 0.694 which indicated that the six independent variables describe 69.4 percent of variations in financial outcome while 30.6 percent is described by different factors outside the model.

Table 4.5: Model Summary

\begin{tabular}{|l|l|r|r|r|r|}
\hline Model & & $\mathrm{R}$ & \multicolumn{1}{|c|}{ R Square } & Adjusted R Square & \multicolumn{2}{|c|}{$\begin{array}{c}\text { Std. Error of the } \\
\text { Estimate }\end{array}$} \\
\hline 1 & & $.784^{\mathrm{a}}$ & .723 & .694 & .632 \\
\hline
\end{tabular}

a. Predictors: (Constant), Mobile Banking Services, Asset Protection, Capital Adequacy, Asset Quality, Costs, Liquidity, Sacco Size

b. Dependent Variable: Financial Performance

\subsubsection{Analysis of Variance}

Analysis of Variance (ANOVA) was done to find the difference in means between independent and dependent variables to discover if they are linked. The ANOVA was done at $95 \%$ confidence interval with the level of significance at $5 \%$. The results in Table 4.6 show significance value of 0.05 that is equal to the p-value. Thus, we eliminate null hypothesis "no coefficients of the independent variables can predict financial performance". The model therefore has statistical significance. This implies that financial performance has an important linear relationship with mobile banking services, asset protection, liquidity, asset quality, capital adequacy, costs, and SACCO size in DTS. 
Table 4.6: Analysis of Variance

\begin{tabular}{|ll|r|r|r|c|c|}
\hline \multicolumn{1}{|l|}{ Model } & Sum of Squares & Df & Mean Square & F & Sig. \\
\hline 1 & Regression & 0.644 & 2 & 0.322 & 1.3529 & $.050^{\mathrm{a}}$ \\
Residual & 9.758 & 115 & 0.238 & & \\
Total & 10.402 & 117 & & & \\
\hline
\end{tabular}

a. Predictors: (Constant), Mobile Banking Services, Asset Protection, Capital

Adequacy, Asset Quality, Costs, Liquidity, Sacco Size

b. Dependent Variable: Financial Performance

\subsubsection{Regression Coefficients}

To verify the connection of dependent and independent variables and their different strengths, the regression analysis generated coefficients as presented below.

Table 4.7: Regression Coefficients

\begin{tabular}{|l|r|r|r|r|r|}
\hline \multirow{2}{*}{ Model } & \multicolumn{2}{|c|}{$\begin{array}{c}\text { Unstandardized } \\
\text { Coefficients }\end{array}$} & $\begin{array}{c}\text { Standardized } \\
\text { Coefficients }\end{array}$ & & \\
\cline { 2 - 4 } & \multicolumn{1}{|c|}{$\mathrm{B}$} & Std. Error & \multicolumn{1}{c|}{ Beta } & \multicolumn{1}{c|}{$\mathrm{T}$} & \multicolumn{1}{c|}{ Sig. } \\
\hline 1 (Constant) & 2.321 & .433 & & 5.360 & .032 \\
Mobile Banking & 0.128 & .230 & .278 & 0.557 & .050 \\
Services & & & & & \\
Asset Protection & 1.613 & .086 & .237 & 6.930 & .049 \\
Capital Adequacy & 2.316 & .063 & .164 & 5.6031 .4 & .036 \\
Asset Quality & 1.963 & .684 & .036 & 08 & .039 \\
Costs & 1.322 & .849 & .250 & 1.557 & .030 \\
Liquidity & 2.247 & .972 & .374 & 2.311 & .028 \\
Sacco Size & 1.023 & .071 & .113 & 3.217 & .048 \\
\hline
\end{tabular}

a. Dependent Variable: Financial Performance

Since all the significance values were less than or equal to the p-value, then the null hypothesis that none of the coefficients in the independent variables can predict financial performance. From the Coefficients Table (Table 4.7), the below stated regression model was derived; 
$Y=\alpha+\beta_{1} X_{1}+\beta_{2} X_{2}+\beta_{3} X_{3}+\beta_{4} X_{4}+\beta_{5} X_{5}+\beta_{6} X_{6}+\beta_{7} X_{7}+\epsilon$

Financial Performance $=\alpha+\beta_{1}$ Mobile Banking Services $+\beta_{2}$ Asset Protection $+\beta_{3}$ Capital Adequacy $+\beta_{4}$ Asset Quality $+\beta_{5}$ Costs $+\beta_{6}$ Liquidity $+\beta_{7}$ Sacco Size $+\epsilon$

Where;

Financial Performance $=2.321+0.128 \mathrm{X}_{1}+1.613 \mathrm{X}_{2}+2.316 \mathrm{X}_{3}+1.963 \mathrm{X}_{4}+1.322 \mathrm{X}_{5}+2.247 \mathrm{X}_{6}+$ $1.023 \mathrm{X}_{7}+\epsilon$

The regression results show that, holding all the independent variables at $95 \%$ confidence interval to a constant zero, the SACCOs' financial performance will be at 2.321. Unit change in Mobile banking services results in a 0.128 change in financial output ceteris paribus and unit changes in Asset Protection bring about 1.613 changes in financial output, ceteris paribus. Similarly, unit changes in Capital Adequacy, Asset Quality, Costs, Liquidity and Sacco Size will lead to $2.316,1.963,1.322,2.247$ and 1.023 changes respectively in financial output, ceteris paribus. The results also show that the most influential variable is Capital Adequacy followed by Liquidity.

\subsection{Discussion of Research Findings}

This study's intention was on revealing how MBS impacts the financial outcome of Kenya's DTS. According to this study, MBS positively influences financial outcome in DTS. The deposits taking SACCOS have recorded improved performance through increase in total assets, total loans, deposits and core capital. Mobile banking transactions have also gradually increased over the period. These findings are similar to those by Munyoki (2015) who found that MBS had increased considerably. Abubakar (2016) in an identical study noted that MBS raise levels of competitiveness within financial institutions. Mobile banking provides financial inclusiveness and increased the convenience to customers (Mwania, 2017).

Mobile banking as well as all the control variables namely asset protection, asset quality, Liquidity, capital adequacy SACCO size, and costs have positive impact on the financial output in DTS. However, Capital adequacy and Liquidity determined financial performance of DTS to a greater extent. For SACCOs to operate optimally and effectively, adequate core capital, liquid assets, deposits and Capital adequacy and Liquidity ratios are maintained. Maaka (2006) found that a big gap in liquidity may lead to borrowing at higher interest rates and reduction in profitability. Mobile phone usage is not only convenient but encourages savings and is accessible, which makes mobile banking attractive and usage accessible even in the comfort of home (Mwania, 2017). A study by Okiro and Ndungu (2013) revealed that SACCOs registered high rates in the use of MBS. 


\section{CHAPTER FIVE \\ SUMMARY, CONCLUSIONS AND RECOMMENDATIONS}

\subsection{Introduction}

The chapter covers the findings' summary and conclusions that follow from these findings. Study limitations, recommendations and areas for additional research are indicated as well.

\subsection{Summary}

From the research findings, it is observed that mobile banking services, asset protection, SACCO size, asset quality, liquidity, costs and capital adequacy were positively correlated to financial outcome of DTS hence implying that they influence it. The study also found that capital adequacy and liquidity determine the financial outcome of DTS to a greater extent. Although all the independent variables were positively correlated, the correlation was not vital.

The average mean for MBS was 3.49and a 0.33 standard deviation, signifying the service was not extensively used by SACCOs and their members although SACCO growth has been rapid over the four- year period as evidenced by the gradual increase in deposits.

The study also found that Deposit Taking SACCOs' growth in terms of assets and loans is gradual. In addition, the number of DTS that have adopted mobile MBS has increased gradually during the period of study but only a few have succeeded in its use due to high capital investments and expertise needed for efficiency.

\subsection{Conclusion}

The study had wanted to find out effect of MBS on financial outcome of Kenya's DTS. The study concludes that mobile banking services, asset protection, capital adequacy, liquidity, SACCO size, asset quality, and costspositively influence financial output in DTS.

In addition, Capital Adequacy and liquidity determine the financial performance of DTS to a greater extent. Another conclusion is that deposit taking SACCOs' growth in terms of deposits, assets and loans is gradual. In addition, majority of deposit taking SACCOs have adopted MBS but only a few have succeeded in its use due to high capital investments and expertise needed for efficiency. Adoption and usage of mobile application systems has also faced challenges including high capital investments and expertise needed for efficiency.

\subsection{Recommendations of the Study}




\section{International Journal of Social Science and Economic Research}

ISSN: $2455-8834$

Volume: 05, Issue: 05 "May 2020"

From the above summary and conclusions, the study recommends that SACCOs embrace new technologies and introduce new products through mobile banking to improve financial performance. Management of SACCOs should allocate adequate funds for new software and training to enhance full automation of operations. Further, SACCOs should make sure that members are aware of MBS and the relevant safety measures. In addition, the government should come up with incentives that can lower the cost of MBS thus encouraging SACCOs that are yet to adopt the innovation to do so.

\subsection{Limitations of the Study}

The study was limited to establishing the effect of MBS on financial output of DTS. Also, the study covered only four years, that is, the period between the years 2015 and 2018. A longer duration of time could have yielded more robust results in terms of significant economic situations with a negative or positive impact. In addition, the study faced limitations in accessing financial reports from SASRA leading to delays in collection of data. The study faced constraints for time in data collection and analysis to complete the project. This was addressed by making frequent follow-ups with SASRA for collection of data.

\subsection{Suggestions for Further Research}

From the above discussion, further studies are needed to establish the relationship between MBS and use of system by customers. Further studies are also needed in which all Deposit Taking SACCOs are included to generalize the findings. In addition, challenges affecting MBS should be studied in order to come up with strategies for improvement. A study on factors that affect financial performance in SACCOS will be beneficial to both SACCOS and SASRA and which may result in improvements of SACCO finances.

\section{REFERENCES}

Aboelmaged, M.G. \& Gebba, T.R. (2013). Mobile banking adoption: An examination of Technology Acceptance Model and Theory of Planned Behavior. International Journal of Business Research and Development, 2(4): 35-50.

Aduda, J. \& King'oo, N. (2012). The Relationship between Electronic Banking and Financial Performance among Commercial Banks in Kenya. Journal of Finance and Investment Analysis, 1 (3). 16-40

Agarwal, R. and Prasad, J. (1998). A Conceptual and Operational Definition of Personal Innovativeness in the Domain of Information Technology. Information Systems Research, 9(1): 204-224. 


\section{International Journal of Social Science and Economic Research}

ISSN: 2455-8834

Volume: 05, Issue: 05 "May 2020"

Al-Hussein, A. H., \& Johnson, R. L. (2009). Relationship between corporate governance efficiency and Saudi banks' performance. The Business Review, 14 (1), 111-17.

Alkhatib, K. (2012). Financial Performance of Palestinian Commercial Banks. International Journal of Business and Social Science, 3(3): 17-39.

Almazari, A. A. (2011). Financial performance evaluation of some selected Jordanian commercial banks. International Research Journal of Finance and Economics, 68(2): 5063.

Al-Tamimi, H.\& Hussein, A. (2010) Factors influencing performance of the UAE Islamic and Conventional National Banks. Global Journal of business Research, 5(4):1-9.

Anyasi, F. I. \& Otubu, P.A. (2009) Mobile Phone Technology in Banking System: It's Economic Effect. Research Journal of Information Technology, 1(1): 1-5.

Baral, K. J. (2006). Financial Health Check-up of Pokhara Royal Co-operative Society Limited in the Framework of PEARLS. Journal of Nepalese Business Studies, 3(1):45-70.

Beck, T., Dermiguc-Kunt, A. \& Martinez, P. M. (2007). Reaching out: access to and use of banking services across countries. Journal of Financial Economic, 85, 234-244.

Christensen, C. M. (2006). The ongoing process of building a theory of disruption. The Journal of Product Innovation Management,23(6): 39-55.

Cooper, D. R., \& Schindler, P. S. (2006). Business Research Methods (9 ${ }^{\text {th }}$ ed.). Chicago, McGraw - Hill/ Irwin.

Crabbe, M., Standing, C., Standing, S. \& Karjaluoto, H. (2009). An adoption model for mobile banking in Ghana. International Journal of Mobile Communications, 7(5), 515-543.

Dabholkar, P. \& Bagozzi, R. (2002). An attitudinal Model of Technology-based Self-Service: Moderating effects of consumers' traits and situational factors. Journal of Academy of Marketing Science, 30 (3), 184-201

Danneels, E. (2004). Disruptive Technology Reconsidered: A Critique and Research Agenda. Journal of Product Innovation Management, 21 (4), 246-258.

Daud, N.M., Kassim, N.E., Said, W.S., \& Noor, M.M. (2011). Determining critical success factors of mobile banking adoption in Malaysia. Australian Journal of Basic and Applied Sciences, 5(5),252-265. 


\section{International Journal of Social Science and Economic Research}

ISSN: $2455-8834$

Volume: 05, Issue: 05 "May 2020"

Davis, F.A. (1989). Perceived usefulness, perceived ease of use, and user acceptance of information technology. MIS Quarterly, 13(1),319-340.

Ensor, B., Montez, T. \& Wannemacher, P. (2012). The State of Mobile Banking, Cambridge, MA: Forrester Research.

Frankfurt School of Finance and Management. (2011). Mobile banking and financial inclusion: The regulatory lessons (166.). Frankfurt: Klein, M. \& Mayer, C.

Gupta, S.P. \& Gupta, M.P. (2010). Business Statistics $\left(16^{\text {th }}\right.$ ed.). New Delhi: Sultan Chand \& Sons Educational Publishers

Hassan, M.K., Bashir, A., 2003. Determinants of Islamic Banking Profitability. Paper Presented at the Proceedings of the Economic Research Forum 10th Annual Conference, Marakesh - Morocco.

Harper W.M. (1991). Statistics (6 ${ }^{\text {th }}$ ed.). Pearson Education Limited

Hernandez, J. (2011). The regulatory landscape of mobile banking. Retrieved August 9, 2018 from https://www.itu.int/ITU-D/treg/Events/Seminars/GSR/

IMF Institute. 2009.IMF Working Paper: Six Puzzles in Electronic Money and Banking (19). Kariuki, N.

Ivatury, G.\& Mas, I. (2008). The early experience with branchless banking. Focus Note 46. Washington, D.C.: CGA P

Jatmiko, D. P. \& Hiyadat, S. (2016). Effects of corporate social responsibility disclosure and environmental performance to financial performance in Indonesia stock exchange. International Journal of Management and Commerce Innovations, 4(2),252-265.

Kaminsky, J. (2011). Diffusion of Innovation Theory, Canadian Journal of Nursing Informatics, $6(2)$.

Karahanna, E., Straub, D. W. \& Chervany, N. L. (1999). Information technology adoption across time: A cross-sectional comparison of pre-adoption and post-adoption beliefs. MIS Quarterly 23 (2), 183-213.

Kiaritha, H. N. (2015). Determinants of the financial performance of Savings and Credit Cooperatives in the banking sector in Kenya. Unpublished $\mathrm{PhD}$ Thesis, Jomo Kenyatta University of Agriculture and Technology 


\section{International Journal of Social Science and Economic Research}

ISSN: $2455-8834$

Volume: 05, Issue: 05 "May 2020"

Kigen, K. P. (2010). The impact of mobile banking on transaction costs of Microfinance Institutions, Unpublished MBA Thesis, University of Nairobi.

King, A. A. \& Baartartogtokh, B. (2015). How useful is the Theory of Disruptive Innovation? Research Gate. MIT Sloan Management Review, Fall 2015:77-90.

Kingoo, H. (2011). The relationship between electronic banking and financial performance of commercial banks in Kenya. Unpublished MBA Thesis, University of Nairobi.

Kiugu, S. K. (2018). Effect of mobile banking on the financial performance of Sacco Societies regulated by the Sacco Societies Regulatory Authority in Kenya. Unpublished MBA Thesis, University of Nairobi

Kivuvo, R. M., \& Olweny, T. (2014). Financial Performance Analysis of Kenya's SACCO Sector Using the Altiman Z Score Model of Corporate Bankruptcy. International Journal of Business and Social Science,5(9):1-18.

Kosmidou, K. (2008). The determinants of banks' profits in Greece during the period of EU financial integration. The Managerial Finance,34 (3), 146-159.

Kothari, C.R. (2005). Research Methodology. New Delhi: New Age International (P) Limited Publishers.

Laudon K. C. \& Laudon J. P. (2007). Essentials of business information systems (7 ${ }^{\text {th }}$ Ed.). Pearson Prentice Hall.

Lee, K. S., Lee, H. S. and Kim, S. Y. (2007). Factors Influencing the Adoption Behavior of Mobile Banking: A South Korean perspective. Journal of Internet Banking and Commerce, 12 (2): 1-9.

Mustafa A.R., Ansari, R. H., \& Younis, M. U. (2012). Does the loan loss provision affect the banking profitability in case of Pakistan? Asian Economic and Financial Review, 2 (7):772-783

Muteke, S. M., (2015). The relationship between financial innovation and financial performance among savings and credit co-operative society in Mombasa County, Kenya. Unpublished MA thesis, University of Nairobi.

Mwania, V. M. (2017). Relationship between financial performance and growth of SACCOs in Kenya. Unpublished MA thesis, University of Nairobi. 


\section{International Journal of Social Science and Economic Research}

ISSN: $2455-8834$

Volume: 05, Issue: 05 "May 2020"

Njeri, O. K, (2013). Effects of financial innovation on the financial performance of deposit taking SACCOs in Nairobi County. Unpublished MA thesis, University of Nairobi.

Nuhiu, A. R., Hoti, A., \& Bektashi, M. (2017). Determinants of commercial banks profitability through analysis of financial performance indicators: Evidence from Kosovo. Verslas: TeorijaIr Praktika, 18 (1), 160-170.

Okiro, K., \& Ndung'u, J. (2013). The impact of mobile and internet banking on performance of financial institutions in Kenya. European Scientific Journal,9(13).

Oyugi, I.G. (2014). The effect of automated service on financial performance of Savings and Credit Cooperative Societies licensed by Sacco Society Regulatory Authority in Kenya. Unpublished MBA Project, University of Nairobi.

Puschel, J., Mazzon, J. A., Hernandez, J. M. (2010). Mobile banking: Proposition of an integrated adoption intention framework. International Journal of Bank Marketing. 28 (5), 389-409.

Swamy, V. (2013). Determinants of bank asset quality and profitability- An empirical assessment. Retrieved from http://mpra.ub.uni-muenchen.de/47513/IBS-Hyderabad.

Rogers, E. (1983). Diffusion of innovations, $3^{\text {rd }}$ ed. New York, NY: Free Press of Glencoe.

Rogers, E. (2003). Diffusion of Innovations, $5^{\text {th }}$ ed. New York, NY: Simon and Schuster.

Rogers, E.M. (Ed) (1962). Diffusion of Innovations. The Free Press of Glencoe, Macmillan Publishing Company.

Ross, S.A., Westerfield, R.W., \&Jordan B.D. (2010). Fundamentals of Corporate Finance (9 ed.). McGraw Hill International Edition.

Sonja, K. R. (2010). Effects of computerization on Saving and Credit Cooperatives in Uganda. Unpublished Master's Thesis, ESB Business School, Reutlingen, Germany

Sufian, F., Chong, R. R., (2008). Determinants of Banks Profitability in a Developing Economy: Empirical Evidence from the Philippines. Asian Academy of Management Journal of Accounting and Finance, 4(2), 91-112.

Tchouassi, G. (2012). Can Mobile Phones Really Work to Extend Banking Services to the Unbanked? Empirical Lessons from Selected Sub-Saharan Africa Countries. International Journal of Development Societies, 1(2), 70-81. 
Tiwari, R., S. Buse, and C. Herstatt (2006). "Mobile Banking as Business Strategy: Impact of mobile Technologies on Customer Behavior and its Implications for Banks", in: Technology Management for the Global Future - Proceedings of PICMET '06, July 8 13, 2006, Istanbul, pp. 1935 - 1946.

Tsuma, R. S., Maniagi, G. M., Odhiambo, A. \& Musiega, D. (2015). Effect of financial innovation on financial performance of savings and credit co-operative society in Kenya: A case study of Kakamega Teachers Co-Operative Society Limited. Journal of Business Studies, 3(3):57-78.

Wambari, P. A. M. (2009). Mobile banking in developing countries. A case study on Kenya. Unpublished MA Thesis. University of Nairobi.

Wanjiru, F. (2015). The effect of mobile SACCO service on the financial performance of licensed deposit-taking SACCOs in Nairobi County. Unpublished MBA Project, University of Nairobi.

World Council of Credit Union. (2009). PEARLS monitoring system (Toolkit series 4). WOCCU, D. C.

Yamane, T. (1967). Statistics, an Introductory Analysis, 2nd Ed., New York: Harper and Row.

\section{APPENDICES}

\section{Appendix 1: Study Population}

\begin{tabular}{|l|l|l|l|}
\hline No. & NAME OF SACCO & No. & NAME OF SACCO \\
\hline 1 & 2NK SACCO SOCIETY LTD & 85 & MWIETHERI SACCO SOCIETY LTD \\
\hline 2 & AFYA SACCO SOCIETY LTD & 86 & $\begin{array}{l}\text { MWINGI MWALIMU SACCO SOCIETY } \\
\text { LTD }\end{array}$ \\
\hline 3 & AGRO-CHEM SACCO SOCIETY LTD & 87 & MWITO SACCO SOCIETY LTD \\
\hline 4 & AINABKOI SACCO SOCIETY LTD & 88 & NACICO SACCO SOCIETY LTD \\
\hline 5 & ALL CHURCHES SACCO SOCIETY LTD & 89 & NAFAKA SACCO SOCIETY LTD \\
\hline 6 & AIRPORTS SACCO SOCIETY LTD & 90 & NANDI FARMERS SACCO SOCIETY \\
\hline 7 & AMICA SACCO SOCIETY LTD & 91 & NATION SACCO SOCIETY LTD \\
\hline 8 & ARDHI SACCO SOCIETY LTD & 92 & NAWIRI SACCO SOCIETY LTD \\
\hline 9 & ASILI SACCO SOCIETY LTD & 93 & NDEGE CHAI SACCO SOCIETY LTD \\
\hline 10 & AZIMA SACCO SOCIETY LTD & 94 & NDOSHA SACCO SOCIETY LTD \\
\hline
\end{tabular}


International Journal of Social Science and Economic Research

ISSN: 2455-8834

Volume: 05, Issue: 05 "May 2020"

\begin{tabular}{|c|c|c|c|}
\hline 11 & BANDARI SACCO SOCIETY LTD & 95 & NG'ARISHA SACCO SOCIETY LTD \\
\hline 12 & BARAKA SACCO SOCIETY LTD & 96 & NOBLE SACCO SOCIETY LTD \\
\hline 13 & $\begin{array}{l}\text { BARATON UNIVERSITY SACCO } \\
\text { SOCIETY LTD }\end{array}$ & 97 & NRS SACCO SOCIETY LTD \\
\hline 14 & BIASHARA SACCO SOCIETY LTD & 98 & NSSF SACCO SOCIETY LTD \\
\hline 15 & $\begin{array}{l}\text { BIASHARA TOSHA SACCO SOCIETY } \\
\text { LTD }\end{array}$ & 99 & NUFAIKA SACCO SOCIETY LTD \\
\hline 16 & BI-HIGH SACCO SOCIETY LTD & 100 & NYALA VISION SACCO SOCIETY LTD \\
\hline 17 & BINGWA SACCO SOCIETY LTD & 101 & $\begin{array}{l}\text { NYAMBENE ARIMI SACCO SOCIETY } \\
\text { LTD }\end{array}$ \\
\hline 18 & BORESHA SACCO SOCIETY LTD & 102 & $\begin{array}{l}\text { NYAMIRA TEA FARMERS SACCO } \\
\text { SOCIETY LTD }\end{array}$ \\
\hline 19 & CAPITAL SACCO SOCIETY LTD & 103 & NYATI SACCO SOCIETY LTD \\
\hline 20 & CENTENARY SACCO SOCIETY LTD & 104 & NEW FORTIS SACCO SOCIETY LTD \\
\hline 21 & CHAI SACCO SOCIETY LTD & 105 & OLLIN SACCO SOCIETY LTD \\
\hline 22 & CHUNA SACCO SOCIETY LTD & 106 & PATNAS SACCO SOCIETY LTD \\
\hline 23 & COMOCO SACCO SOCIETY LTD & 107 & PRIME TIME SACCO \\
\hline 24 & COSMOPOLITAN SACCO SOCIETY LTD & 108 & PUAN SACCO SOCIETY LTD \\
\hline 25 & COUNTY SACCO SOCIETY LTD & 109 & QWETU SACCO SOCIETY LTD \\
\hline 26 & DAIMA SACCO SOCIETY LTD & 110 & $\begin{array}{l}\text { RACHUONYO TEACHERS SACCO } \\
\text { SOCIETY LTD }\end{array}$ \\
\hline 27 & DHABITI SACCO SOCIETY LTD & 111 & SAFARICOM SACCO SOCIETY LTD \\
\hline 28 & DIMKES SACCO SOCIETY LTD & 112 & SHERIA SACCO SOCIETY LTD \\
\hline 29 & DUMISHA SACCO SOCIETY LTD & 113 & SHIRIKA SACCO SOCIETY LTD \\
\hline 30 & ECO-PILLAR SACCO SOCIETY LTD & 114 & SIMBA CHAI SACCO SOCIETY LTD \\
\hline 31 & EGERTON SACCO SOCIETY LTD & 115 & SIRAJI SACCO SOCIETY LTD \\
\hline 32 & $\begin{array}{l}\text { ELGON TEACHERS SACCO SOCIETY } \\
\text { LTD }\end{array}$ & 116 & SKYLINE SACCO SOCIETY LTD \\
\hline 33 & ELIMU SACCO SOCIETY LTD & 117 & $\begin{array}{l}\text { SMART CHAMPIONS SACCO SOCIETY } \\
\text { LTD }\end{array}$ \\
\hline 34 & ENEA SACCO SOCIETY LTD & 118 & SMART LIFE SACCO SOCIETY LTD \\
\hline 35 & FARIDI SACCO SOCIETY LTD & 119 & SOLUTION SACCO SOCIETY LTD \\
\hline 36 & FARIJI SACCO SOCIETY LTD & 120 & SOTICO SACCO SOCIETY LTD \\
\hline 37 & FORTUNE SACCO SOCIETY LTD & 121 & $\begin{array}{l}\text { SOUTHERN STAR SACCO SOCIETY } \\
\text { LTD }\end{array}$ \\
\hline 38 & FUNDILIMA SACCO SOCIETY LTD & 122 & SHOPPERS SACCO SOCIETY LTD \\
\hline 39 & $\begin{array}{l}\text { GITHUNGURI DAIRY\& COMMUNITY } \\
\text { SACCO SOCIETY LTD }\end{array}$ & 123 & STAKE KENYA SACCO SOCIETY LTD \\
\hline 40 & GOOD HOPE SACCO SOCIETY LTD & 124 & STIMA SACCO SOCIETY LTD \\
\hline 41 & GOODWAY SACCO SOCIETY LTD & 125 & $\begin{array}{l}\text { SUBA TEACHERS SACCO SOCIETY } \\
\text { LTD }\end{array}$ \\
\hline
\end{tabular}


International Journal of Social Science and Economic Research

ISSN: 2455-8834

Volume: 05, Issue: 05 "May 2020"

\begin{tabular}{|c|c|c|c|}
\hline 42 & GUSII MWALIMU SACCO SOCIETY LTD & 126 & SUKARI SACCO SOCIETY LTD \\
\hline 43 & HARAMBEE SACCO SOCIETY LTD & 127 & SUPA SACCO SOCIETY LTD \\
\hline 44 & HAZINA SACCO SOCIETY LTD & 128 & TABASAMU SACCO SOCIETY LTD \\
\hline 45 & IG SACCO SOCIETY LTD & 129 & TAI SACCO SOCIETY LTD \\
\hline 46 & ILKISONKO SACCO SOCIETY LTD & 130 & TAIFA SACCO SOCIETY LTD \\
\hline 47 & IMARIKA SACCO SOCIETY LTD & 131 & TAQWA SACCO SOCIETY LTD \\
\hline 48 & IMARISHA SACCO SOCIETY LTD & 132 & TEMBO SACCO SOCIETY LTD \\
\hline 49 & IMENTI SACCO SOCIETY LTD & 133 & TENHOS SACCO SOCIETY LTD \\
\hline 50 & JACARANDA SACCO SOCIETY LTD & 134 & THAMANI SACCO SOCIETY LTD \\
\hline 51 & JAMII SACCO SOCIETY LTD & 135 & $\begin{array}{l}\text { TRANSCOUNTIES SACCO SOCIETY } \\
\text { LTD }\end{array}$ \\
\hline 52 & JOINAS SACCO SOCIETY LTD & 136 & TRANS NATION SACCO SOCIETY LTD \\
\hline 53 & KAIMOSI SACCO SOCIETY LTD & 137 & TIMES U SACCO SOCIETY LTD \\
\hline 54 & $\begin{array}{l}\text { KATHERA RURAL SACCO SOCIETY } \\
\text { LTD }\end{array}$ & 138 & TOWER SACCO SOCIETY LTD \\
\hline 55 & KENPIPE SACCO SOCIETY LTD & 139 & $\begin{array}{l}\text { TRANS - ELITE COUNTY SACCO } \\
\text { SOCIETY LTD }\end{array}$ \\
\hline 56 & KENVERSITY SACCO SOCIETY LTD & 140 & $\begin{array}{l}\text { TRANSNATIONAL TIMES SACCO } \\
\text { SOCIETY LTD }\end{array}$ \\
\hline 57 & $\begin{array}{l}\text { KENYA ACHIEVAS SACCO SOCIETY } \\
\text { LTD }\end{array}$ & 141 & UFANISI SACCO SOCIETY LTD \\
\hline 58 & $\begin{array}{l}\text { KENYA BANKERS SACCO SOCIETY } \\
\text { LTD }\end{array}$ & 142 & $\begin{array}{l}\text { UKRISTO NA UFANISI WA } \\
\text { ANGLICANA SACCO SOCIETY LTD }\end{array}$ \\
\hline 59 & $\begin{array}{l}\text { KENYA HIGHLANDS SACCO SOCIETY } \\
\text { LTD }\end{array}$ & 143 & UKULIMA SACO SOCIETY LTD \\
\hline 60 & KENYA POLICE SACCO SOCIETY LTD & 144 & UNAITAS SACCO SOCIETY LTD \\
\hline 61 & KIMBILIO DAIMA SACCO SOCIETY LTD & 145 & UNI-COUNTY SACCO SOCIETY LTD \\
\hline 62 & KINGDOM SACCO SOCIETY LTD & 146 & $\begin{array}{l}\text { UNITED NATIONS SACCO SOCIETY } \\
\text { LTD }\end{array}$ \\
\hline 63 & KIPSIGIS EDIS SACCO SOCIETY LTD & 147 & UNISON SACCO SOCIETY LTD \\
\hline 64 & KITE SACCO SOCIETY LTD & 148 & $\begin{array}{l}\text { UNIVERSAL TRADERS SACCO } \\
\text { SOCIETY LTD }\end{array}$ \\
\hline 65 & KITUI TEACHERS SACCO SOCIETY LTD & 149 & $\begin{array}{l}\text { VIHIGA COUNTY FARMERS SACCO } \\
\text { SOCIETY LTD }\end{array}$ \\
\hline 66 & KMFRI SACCO SOCIETY LTD & 150 & VIKTAS SACCO SOCIETY LTD \\
\hline 67 & KOLENGE TEA SACCO SOCIETY LTD & 151 & VISION POINT SACCO SOCIETY LTD \\
\hline 68 & KORU SACCO SOCIETY LTD & 152 & VISION AFRICA SACCO SOCIETY LTD \\
\hline 69 & K - PILLAR SACCO SOCIETY LTD & 153 & $\begin{array}{l}\text { WAKENYA PAMOJA SACCO SOCIETY } \\
\text { LTD }\end{array}$ \\
\hline 70 & K - UNITY SACCO SOCIETY LTD & 154 & $\begin{array}{l}\text { WAKULIMA COMMERCIAL SACCO } \\
\text { SOCIETY LTD }\end{array}$ \\
\hline
\end{tabular}


International Journal of Social Science and Economic Research

ISSN: $2455-8834$

Volume: 05, Issue: 05 "May 2020"

\begin{tabular}{|l|l|c|l|}
71 & KWETU SACCO SOCIETY LTD & 155 & WANA - ANGA SACCO SOCIETY LTD \\
\hline 72 & LAINISHA SACCO SOCIETY LTD & 156 & WANANCHI SACCO SOCIETY LTD \\
\hline 73 & LENGO SACCO SOCIETY LTD & 157 & WANANDEGE SACCO SOCIETY LTD \\
\hline 74 & MAFANIKIO SACCO SOCIETY LTD & 158 & WASHA SACCO SOCIETY LTD \\
\hline 75 & MAGADI SACCO SOCIETY LTD & 159 & WAUMINI SACCO SOCIETY LTD \\
\hline 76 & MAGEREZA SACCO SOCIETY LTD & 160 & WEVARSITY SACCO SOCIETY LTD \\
\hline 77 & MAISHA BORA SACCO SOCIETY LTD & 161 & WINAS SACCO SOCIETY LTD \\
\hline 78 & MENTOR SACCO SOCIETY LTD & 162 & YETU SACCO SOCIETY LTD \\
\hline 79 & $\begin{array}{l}\text { METROPOLITAN NATIONAL SACCO } \\
\text { SOCIETY LTD }\end{array}$ & 163 & JITEGEMEE SACCO SOCIETY LTD \\
\hline 80 & MMH SACCO SOCIETY LTD & 164 & NANDI HEKIMA SACCO SOCIETY LTD \\
\hline 81 & MOMBASA PORT SACCO SOCIETY LTD & 165 & LTD \\
\hline 82 & $\begin{array}{l}\text { MUDETE TEA GROWERS SACCO } \\
\text { SOCIETY LTD }\end{array}$ & 166 & UCHONGAJI SACCO SOCIETY LTD \\
\hline 83 & MUKI SACCO SOCIETY LTD & & \\
\hline 84 & $\begin{array}{l}\text { MWALIMU NATIONAL SACCO SOCIETY } \\
\text { LTD }\end{array}$ & & \\
\hline
\end{tabular}

\section{Appendix 2: Study Sample}

\begin{tabular}{|ll|}
\hline \multicolumn{1}{|l|}{ SACCO SOCIETY } \\
\hline 1. & AFYA SACCO SOCIETY LTD \\
\hline 2. & AGRO-CHEM \\
\hline 3. & AINABKOI \\
\hline 4. & AIRPORTS \\
\hline 5. & AMICA \\
\hline 6. & ARDHI \\
\hline 7. & ASILI \\
\hline 8. & AZIMA \\
\hline 9. & BANDARI \\
\hline 10. & BARAKA \\
\hline 11. & BARATON UNIVERSITY \\
\hline 12. & BIASHARA \\
\hline 13. & BINGWA \\
\hline 14. & CAPITAL \\
\hline 15. & CENTENARY \\
\hline 16. & CHUNA \\
\hline 17. & COSMOPOLITAN \\
\hline
\end{tabular}


International Journal of Social Science and Economic Research

ISSN: $2455-8834$

Volume: 05, Issue: 05 "May 2020"

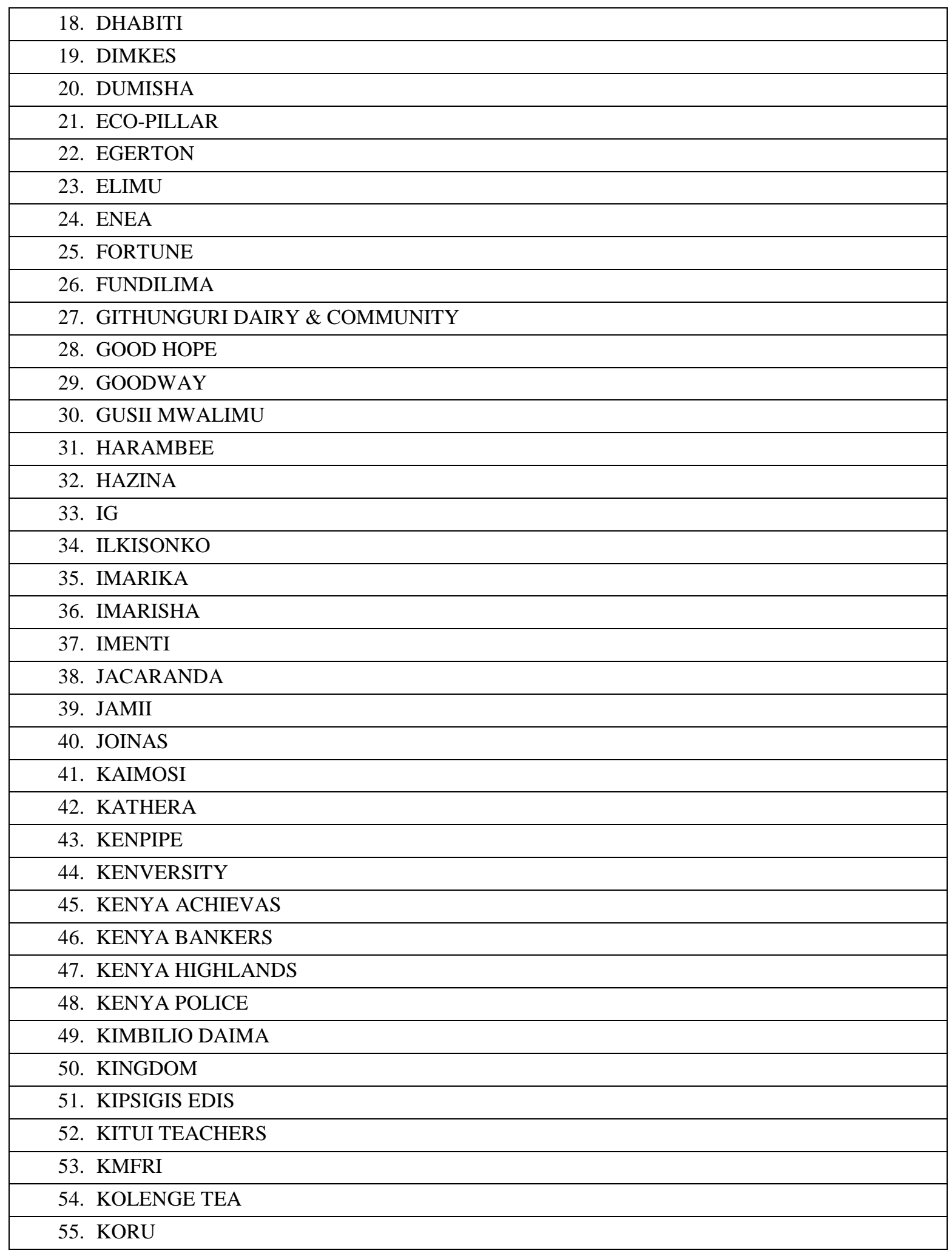




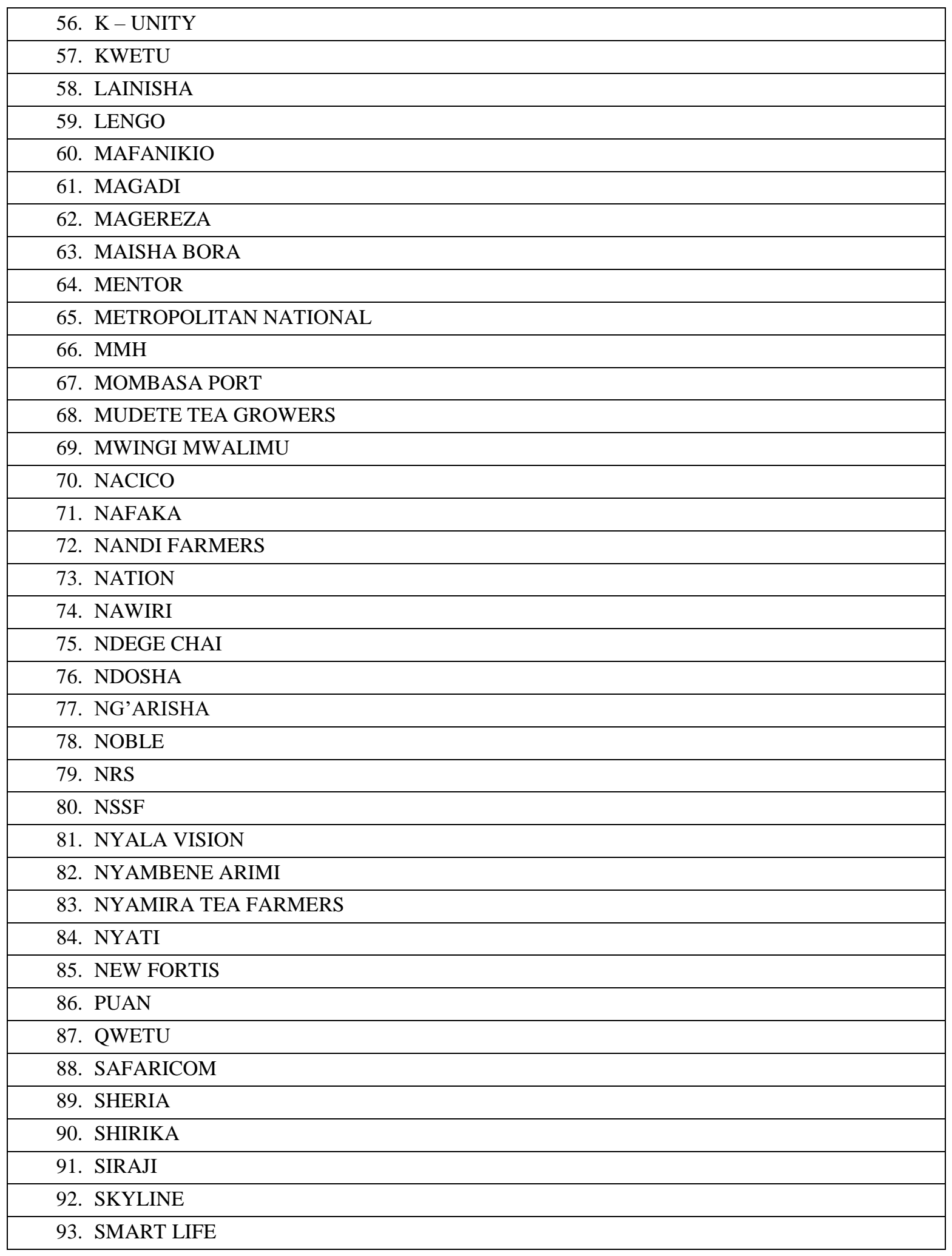


International Journal of Social Science and Economic Research

ISSN: 2455-8834

Volume: 05, Issue: 05 "May 2020"

\begin{tabular}{|l|}
\hline 94. SOTICO \\
\hline 95. SOUTHERN STAR \\
\hline 96. SHOPPERS \\
\hline 97. STIMA \\
\hline 98. SUBA TEACHERS \\
\hline 99. TEMBO \\
\hline 100.THAMANI \\
\hline 101.TIMES U \\
\hline 102. TOWER \\
\hline 103. TRANS - ELITE COUNTY \\
\hline 104. UKULIMA \\
\hline 105.UNAITAS \\
\hline 106. UNI-COUNTY \\
\hline 107. UNISON \\
\hline 108. VISION POINT \\
\hline 109. VISION AFRICA \\
\hline 110. WAKENYA PAMOJA \\
\hline 111. WAKULIMA COMMERCIAL \\
\hline 112. WANA - ANGA \\
\hline 113. WAUMINI \\
\hline 114. WINAS \\
\hline 115. YETU \\
\hline $116 . J I T E G E M E E$ \\
\hline 117. NANDI HEKIMA \\
\hline
\end{tabular}

